Western Washington University Western CEDAR

1991

\title{
Analogous Reference Tools Produced by the U.S. and Canadian Federal Governments
}

\author{
Robert Lopresti \\ Western Washington University, robert.lopresti@wwu.edu
}

Follow this and additional works at: https://cedar.wwu.edu/library_facpubs

Part of the Library and Information Science Commons

\section{Recommended Citation}

Lopresti, Robert, "Analogous Reference Tools Produced by the U.S. and Canadian Federal Governments" (1991). Western Libraries Faculty and Staff Publications. 34.

https://cedar.wwu.edu/library_facpubs/34 


\title{
ANALOGOUS REFERENCE TOOLS PRODUCED BY THE U.S. AND CANADIAN FEDERAL GOVERNMENTS*
}

\author{
ROBERT LOPRESTI** \\ Government Documents Librarian, Wilson Library, Western Washington University, Bellingham, WA, 98225 USA
}

\begin{abstract}
This guide lists a number of U.S. government publications frequently used as reference tools in libraries and compares them to Canadian government publications that contain similar material and may be used in similar fashion. Some U.S. and Canadian publications with no equivalent in the other country are also indicated.
\end{abstract}

\section{INTRODUCTION}

The United States and Canada share one of the world's longest borders. The two nations have much in common besides geographic proximity; there are strong historical, political, and linguistic ties. The two countries trade more goods and services than any other two countries in the world [1]. They are also afflicted by a number of problems in common, such as acid rain.

Given the many links between the two nations, it is not surprising that the two federal governments publish many documents that are similar in form and content. That similarity can be helpful to the library user who seeks comparative information on the two nations.

This article contains a listing and description of U.S. government publications frequently used in answering reference questions, paired with analogous publications of the Canadian government. Other titles are listed to indicate that they have no obvious parallels. Major tools created by commercial publishers are also listed.

Prices are not given due to the frequency with which they change. Unless otherwise indicated, the publications may be ordered from the following sources:

U.S. documents:

Superintendent of Documents

U.S. Government Printing Office

Washington, DC, USA 20402

(202) 783-3238

Canadian documents:

Canadian Government Publishing Centre

Supply and Services Canada

Ottawa, Ontario, Canada K1A OS9

(819) $997-2560$

\footnotetext{
*The author would like to thank Suzanne Dodson and Mary Luebbe, both of the University of British Columbia, for many suggestions and improvements.

${ }^{* *}$ Robert Lopresti is the government documents librarian at Western Washington University. He was formerly the government documents librarian at William Paterson College. He has been an officer of the Documents Association of New Jersey and a member of the New Jersey State Librarian's Depository Advisory Council.
} 
Corporate authors and titles are given in all cases. Superintendent of Documents (Sudoc) classification numbers are given for U.S. publications and Canadian classification numbers for the Canadian. The list assumes reader familiarity with the publications of at least one of the two countries, so the annotations contrast the publications rather than giving a detailed description of each.

Publications of the various censuses are not listed, except for basic material (numbers 21 and 22 below), because the census publications are too complex to cover within the context of this article. As this is being written the publications of Statistics Canada's Health Division are undergoing significant revision and for that reason publications about vital statistics are not included here.

One additional caveat is that while different publications may appear to cover the same subject, they may not approach or define the topic in the same way. One should never assume, for example, that statistics from two different governments, or even two branches of the same government, are directly comparable without first making a careful scrutiny of the definitions and the introductory text.

\section{BIBLIOGRAPHIC INFORMATION}

1A. Monthly Catalog of United States Government Publications. (MC) U.S. Government Printing Office. GP 3.8: (year/month).

B. Government of Canada Publications Catalogue. Canada. Department of Supply and Services. IC 6-1/(volume-issue).

These titles are the major indices to government publications for their respective countries. The Canadian version, which is published quarterly, is on a smaller scale than the $M C$. It does not, for example, contain full MARC records. Both publications contain an index in each issue and have a cumulative annual index. $M C$ also has a cumulative half-year index. The U.S. product contains more elaborate indexing, including indices of keywords and contract numbers.

2. Microlog: Canadian Research Index. Micromedia Limited. Toronto, Ontario.

Microlog is a commercially produced index to Canadian federal and provincial documents. Micromedia also makes the indexed publications available on microfiche. There is no equivalent publication for general U.S. federal and state documents.

3A. Library of Congress Subject Headings. (LCSH) U.S. Library of Congress. Cataloging Distribution Service. LC 26.7: (edition/volume).

B. Canadian Subject Headings. (CSH) Canada. National Library. SN 3-106/(year).

$C S H$ is not a Canadian substitute for $L C S H$, but is rather a supplement to it. Its purpose is to provide headings for details of Canadian his- 
tory, politics and social issues, and so forth, which the Library of Congress does not supply. Cumulative supplements to $C S H$ have been made available as part of the National Library of Canada's publication Bibliotech, but no further supplements are expected until the new edition in 1991.

4A. Publications Reference File. (PRF) U.S. Government Printing Office. Sales Management Division. GP 3.22/3: (date)

B. Inventory Master List. Canada. Department of Supply and Services. No classification number.

These are microfiche lists of documents currently for sale from the main government printing agency of each country. The U.S. set is issued every two months and has indices by title, Sudoc number, and stock number. The Canadian set, issued quarterly, has indices by title and classification number.

\section{GOVERNMENT ORGANIZATION}

5A. United States Government Manual. U.S. National Archives and Records Administration. AE 2. 108/2: (year).

B. Guide to Federal Programs and Services. Canada. Department of Supply and Services. P 38-4/1-(year).

These volumes provide information on the workings of federal agencies. The U.S. book is primarily concerned with structure. Divisions are listed within departments, and organization charts are provided. The Canadian book emphasizes programs rather than structure, and agencies are arranged by the subjects they deal with. Both books provide addresses and phone numbers for federal agencies. The U.S. volume lists the names of key officials. The Canadian volume includes all local offices of federal agencies.

6. Catalog of Federal Domestic Assistance. U.S. Executive Office of the President. Office of Management and Budget. PrEx 2.20: (year).

The Catalog is a compendium of federal government programs that provide assistance or benefits to people in the United States. It is frequently used as a source of grant information and contains indices by subject, agency, and the type of organization or individual who can apply. There is no exact match from the Canadian government. The Guide to Federal Programs and Services (see 5B above) contains similar information, but with significantly less detail. The Canadian Guide describes each program in a single paragraph, while the U.S. Catalog 
usually offers a full page of detail, including procedures, obligations, and sources of further information.

7A. U.S. Congressional Directory. U.S. Congress. Joint Committee on Printing. Y 4.P 93/1: $1 /$ (congress/issue).

B. Canadian Parliamentary Guide. Syndicat des Oeuvres Sociales Limité. Ottawa, Ontario. Corpus Administrative Index. Corpus Information Systems. Don Mills, Ontario.

The Congressional Directory is the official handbook for the United States Congress. It provides biographical data on each congressman, as well as membership data on congressional committees and commissions. Other sections list officials in the executive and judicial branches, U.S. and foreign diplomats, and journalists admitted to the congressional press gallery. Canada has no official equivalent but the two commercially published books listed in 7B provide similar information about that country's government.

8. Citizen's Guide. Canada. Department of Supply and Services. P 64-4/ (year).

This pocket-size guide to the Canadian federal government has no clear U.S. analog. The guide's purpose is to answer the most frequently asked questions about government services. It uses a simple " $Q$ and A" format to direct readers to the right place to apply for a copyright, a pardon, a job as an astronaut, and so forth.

9. Government of Canada Telephone Directory. Canada. Department of Communications. Government Telecommunications Agency. CO 35-1/(year)-1.

The Canadian government publishes phone books intended for use by government employees. Each directory is regional (the classification number above is for the National Capital Region directory). Each book also contains nationwide directories for facsimile machines (FAX), communicating word processors and telecommunication devices for the hearing- and speech-impaired (TDD and TTY). In the United States, by comparison, major federal agencies and some subagencies continue to produce their own telephone directories, which are usually sent to depository libraries in a microfiche format.

\section{LAWS AND THE LEGISLATIVE PROCESS}

10A. Slip Laws. U.S. National Archives and Records Administration. AE 2. 110:(Congresslaw number).

B. Statutes. Canada. Department of Supply and Services. YX 3-(year/number). Canada Gazette. Part III. Canada. Department of Supply and Services. SP 2-11/ (volume/ number). 
Individually published laws may be purchased in both countries. In addition, Canada Gazette Part III publishes the Acts (or Statutes) after Parliamentary approval, when a sufficient number have accumulated. It also contains occasional ancillary items, such as the "Table of Public Statutes From 1907 to the Present." For Parts I and II of the $G a$ zette, see $17 \mathrm{~B}$.

11A. U.S. Statutes at Large. U.S. National Archives and Records Administration. AE 2.111: (year/part).

B. Statues of Canada. Canada. Parliament. YX 2-(parliament/session/volume).

These titles contain the laws in numerical order. The U.S. volumes contain proclamations and concurrent resolutions.

12A. U.S. Code. Congress. Y 1.2/5: (year/volume).

B. Revised Statutes of Canada. Canada. Parliament. YX 44-(year/volume).

These publications are not direct parallels because Canadian laws are not codified; that is, they are not broken down in a subject arrangement. Instead, each act is listed separately (i.e., Chapter M-3, the Meat Import Act). Both sets list the laws currently in effect. The U.S. set is revised every six years, with annual supplements. The Canadian version is revised every 15 to 20 years.

13. Congressional Information Service. (CIS) Congressional Information Service. Bethesda, Maryland.

CIS is a commercially produced index to publications of the U.S. Congress. It is the best source for information on congressional hearings, reports, and committee prints. The full text of these publications are available in microfiche from the company. There is no Canadian equivalent.

14A. CRS Issue Briefs. U.S. Library of Congress. Congressional Research Service. No Sudoc number.

B. Current Issue Reviews. Canada. Library of Parliament. Research Branch. YM 32-1/(yearnumber).

Backgrounder. Canada. Library of Parliament. Research Branch. YM 32-3/(number).

C. 1916-1989 Cumulative Index To CRS Reports. University Publications of America. Bethesda, Maryland.

Major Studies and Issue Briefs of the Congressional Research Service. University Publications of America. Bethesda, Maryland. 
The publications listed as $12 \mathrm{~A}$ and $\mathrm{B}$ are brief, nonpartisan summaries of important issues facing the legislative bodies of their respective nations, and are, in fact, written for the legislators and their staff. Along with a summary of the problem, they usually contain a chronology and a bibliography. The Canadian publications are available free to Canadian depository libraries and may also be purchased from the Department of Supply and Services. A list of them is available from the Library of Parliament. The U.S. documents are not directly available to depository libraries or to the public, and can only be requested through the office of a member of Congress. While the U.S. government makes no list of Issue Briefs available, the index published commercially by University Publications of America (UPA) (14C above) lists Congressional Research Service (CRS) briefs and major studies. UPA also sells a microfilm set of the reports, under the title Major Studies and Issue Briefs of the Congressional Research Service.

15. CRS Review. U.S. Library of Congress. Congressional Research Service. LC 14.19: (volume/issue).

The CRS Review is a periodical published approximately nine times each year by the Congressional Research Service. The articles discuss major policy issues, as well as topics specifically of interest to legislators, such as the separation of powers, and congressional leadership. Articles by guest authors such as John Kenneth Galbraith sometimes appear. There are always lists of related CRS documents, available only to congressional offices. There is no Canadian equivalent.

16. Major Legislation of Congress. (MLC) U.S. Library of Congress. Congressional Research Service. LC 14.18:(congress/issue).

Approximately five cumulating issues of this serial are published during each Congress (a two-year period). The goal is to summarize major issues before Congress and describe what has been done (in terms of bills introduced, hearings held, and laws passed) on each topic. By examining the final issues of $M L C$ for several congresses it is possible to trace legislative efforts on one subject over a number of years. Indexes by title and bill or law numbers are provided. A subject index would be useful. There is no Canadian equivalent.

\section{REGULATIONS AND RULINGS}

17A. Federal Register. U.S. National Archives. AE 2.106:(volume/number).

B. Canada Gazette Part I. Canada. Department of Supply and Services. SP 2-1/(volume/ number).

Canada Gazette Part II. Canada: Department of Supply and Services. SP 2-2/(volume/ number). 
The Federal Register lists proposed and final regulations of U.S. executive agencies as well as meeting announcements and some kinds of official notices. It is published five days a week. The Canada Gazette Part II contains final regulations and is published every two weeks. Part $I$ is published every Saturday and contains proposed regulations, as well as a broader range of notices than are found in the Federal Register. These may include Parliamentary notices as well as dividend and meeting information from federally chartered banks and corporations. For Part III of the Canada Gazette, see 10B.

18A. U.S. Code of Federal Regulations. (CFR) U.S. National Archives and Records Administration. Office of the Federal Register. AE 2.106/3:(title/part/year).

B. Consolidated Regulations of Canada. Canada. Department of Supply and Services. SP 2-2/1978.

The CFR is an annually updated list of current regulations, arranged by subject. The Canadian publication lists regulations current as of 1978. A two volume supplement carries it through 1979. To update beyond this point requires a complete run of Canada Gazette Part II (see 17B), which also occasionally publishes a "Consolidated Index of Statutory Instruments." Office consolidations are available for some Canadian regulations. Microfiche revisions of other regulations are available on subscription. Each amended microfiche is listed in the Government of Canada Publications Catalogue (see 1B).

19A. Regulatory Program of the United States Government. U.S. Executive Office of the President. Office of Management and Budget. PrEx 2.30: (years).

B. Federal Regulatory Plan. Canada. Office of Privatization and Regulatory Affairs. BT 57$2 /$ (year).

These publications serve as an early warning system, announcing the major regulatory changes the administration plans to pursue in the given period. Each contains a subject index.

20A. Slip Opinions. U.S. Supreme Court. Ju 6.8/b:(year/docket number). U.S. Reports. U.S. Supreme Court. Ju 6.8:(volume).

B. Canada Supreme Court Reports. Canada. Department of Supply and Services. Ju 1-1/ (year/part-volume).

The only significant difference between these two publications is format. The U.S. Supreme Court decisions are first issued individually before being collected into bound volumes of U.S. Reports. 


\section{STATISTICAL TOOLS}

21A. Statistical Abstract of the United States. U.S. Department of Commerce. Bureau of the Census. C 3.134: (year).

B. Canada Year Book. Canada. Statistics Canada. CS 11-402E/(year).

These are the main publications summarizing statistics for their respective countries. The Abstract is published annually, while the Year Book, in spite of its name, comes out every two-to-three years. The Abstract contains twice as many tables as the Year Book, which relies more heavily on text. The Abstract is an effective aid to finding more detailed information because each table lists the title of the publication from which the data were drawn. In contrast, the Year Book offers only the name of the agency that provided the information. The current edition of the Year Book contains several useful appendices, including descriptions of federal agencies, the names of government officials, and a copy of the Canadian Constitution.

22A. Historical Statistics of the United States, Colonial Times to 1970. U.S. Department of Commerce. Census Bureau. C 3.134/2: H 62/789-970/pt. 1 and 2.

B. Historical Statistics of Canada. Canada. Statistics Canada. CS 11-516E.

These works are excellent collections of historical data for their respective countries. The Canadian tables generally begin at 1870 or later. Some of the basic U.S. material goes back to 1790 .

23. American Statistics Index (ASI). Congressional Information Service. Bethesda, Maryland.

This commercially published tool is an index to U.S. federal documents containing statistics. Microfiche copies of the publications cited are available for purchase from CIS. There is no Canadian equivalent.

24A. Crime in the United States: Uniform Crime Reports. U.S. Department of Justice. Federal Bureau of Investigation. J 1.14/7:(year).

B. Crime Statistics. Canada. Statistics Canada. CS 85-205/(year).

Both of these volumes of basic crime statistics contain geographic and categoric breakdowns. The FBI volume also gives statistics on persons arrested and on the number of law enforcement personnel.

25A. The Condition of Education: A Statistical Report. U.S. Department of Education. Office of Educational Research and Improvement. Center for Educational Statistics. ED 1.109: (year). 
B. Education in Canada: A Statistical Review. Canada. Statistics Canada. CS 81-229/(year).

These volumes contain major summaries of educational statistics and indicators for their respective countries. The Canadian book is more detailed about fields of study and about the provincial/state level. The U.S. book, on the other hand, provides statistics on such subjects as job satisfaction, and school library resources, which its Canadian counterpart does not.

26. Canada - A Portrait. Canada. Statistics Canada. CS 11-403/(year).

This Canadian document, previously entitled Canada Handbook, has no real U.S. equivalent. It is an overview of conditions in the country, containing brief reports on everything from provincial parks to mineral production. The emphasis is on color photos and summary information, rather than on statistical tables.

\section{FOREIGN RELATIONS}

27A. Treaties in Force. U.S. State Department. S 9.14:(year).

B. Treaties in Force. Canada. Department of External Affairs. E 1-2/(year).

These publications are similar in design and content. Each contains two parts: a list of bilateral agreements, followed by a list of multilateral agreements. Both are updated annually.

28A. Diplomatic List. U.S. Department of State. S 1.8:(year/number).

B. Diplomatic, Consular, and Other Representatives in Canada. Canada. Department of External Affairs. E 12-3/(year-issue).

Both of these documents, which are updated more than once each year, contain a list of foreign representatives in the respective countries. They also contain phone numbers and addresses for embassies. In addition, the Canadian publication lists consulates and the offices of international organizations.

29A. Key Officers of Foreign Service Posts: Guide For Business Representatives. U.S. Department of State. S 1. 40/4:(year/number).

B. Canadian Representatives Abroad. Canada. Department of External Affairs. E 12-5/ (year). 
These books list the addresses of their countries' embassies and consulates in foreign nations, as well as the names and posts of representatives.

\section{BUSINESS INFORMATION}

30A. Standard Industrial Classification Manual. U.S. Executive Office of the President. Office of Management and Budget. PrEx 2.6/2:In 27/(year).

B. Standard Industrial Classification. Canada. Statistics Canada. CS 12-501.

The SICS of both nations are designed to classify business establishments by their activities. The SIC numbers are used in categorizing census and other economic statistics. The formats are very similar: a two-digit number for each major group, a three-digit number for each group, and so on, but the actual division and grouping varies because the two countries have different industrial structures.

31A. Business Statistics. U.S. Department of Commerce. Bureau of the Census. C 59.11/3: (year).

B. Canadian Economic Observer: Historical Supplement. Statistics Canada. CS 11-210/ (year).

Each of these books presents a summary of economic statistics. The U.S. volume is more detailed, particularly by industry. The Canadian volume is an annual supplement to the Canadian Economic Observer, a monthly economic journal that is published by the government. The U.S. document is a biennial supplement to the Survey of Current Business.

32A. Commerce Business Daily. U.S. Department of Commerce: C 1.76: (issue).

B. Government Business Opportunities. Canada. Department of Supply and Services. 12-6/ (volume/issue).

Both publications list proposed procurements of goods and services by their respective governments, so that interested businesses may submit bids. They also list contract awards and relevant notices. The Canadian publication was started in 1989 as a direct response to the Free Trade Agreement. It changed from weekly to daily publication in April 1990.

33A. CPI Detailed Report. U.S. Department of Labor. Bureau of Labor Statistics. L 2.38/3: (year/month). 
B. Consumer Prices and Price Indexes. Canada. Statistics Canada. CS 62-010/(volume/ issue).

The Consumer Price Index. Canada. Statistics Canada. CS 62-001/(volume/issue).

These reports on the Consumer Price Index in the respective countries are very similar. The U.S. report is issued monthly. Canada's Consumer Prices and Price Indexes is issued quarterly. The Consumer Price Index is issued monthly, and contains less detail.

34A. Minerals Yearbook. U.S. Department of the Interior. Bureau of Mines. I 28.37:987/ v.1,2,3.

B. Canadian Minerals Yearbook: Review and Outlook. Canada. Energy Mines and Resources Canada. M 38-5/37-(year).

The Canadian book resembles Volume I of the U.S. publication. There is no Canadian equivalent for the U.S. Volume II, Domestic Area Reports, or Volume III, International Area Reports.

\section{LABOR INFORMATION}

35A. Occupational Outlook Handbook. $(\mathrm{OOH})$ U.S. Department of Labor. Bureau of Labor Statistics. L 2.3/4: (years).

B. Job Futures. Canada. Employment and Immigration Canada. MP 43-181/1989-1-1, 2, 3.

Volume I of the Canadian publication, "Experience of Recent Graduates," has no close U.S. equivalent. It reports on the outcome of secondary education in various fields by noting the number of graduates and the fields they entered after receiving their degrees. Volume II, "Occupational Outlooks," is similar to the U.S. $O O H$, listed above, in that they both summarize different occupations in terms of skills and training needed, future prospects, and earnings. The U.S. book uses more specific categories, while the Canadian volume illustrates its information with useful charts. The third Canadian volume, called "The Handbook," is a summary of information from the first two volumes.

36A. Dictionary of Occupational Titles. (DOT) U.S. Department of Labor. Employment and Training Administration. L 37.302:Oc 1.

B. Canadian Classification and Dictionary of Occupations. (CCDO) Canada. Employment and Immigration Canada. Major Groups: MP 53-1/ (group-year) Guide: MP 53-8/(year).

$D O T$ and $C C D O$ are elaborate classification systems for occupations, and both contain one-paragraph definitions of each listed job. The U.S. 
book lists about 20,000 occupations, compared to 7,700 in the Canadian set, but the $C C D O$ provides more information (such as working conditions and aptitude factors), through an elaborate set of codes. The $C C D O$ currently consists of seven large booklets; the DOT is one large volume.

37. Handbook of Labor Statistics. U.S. Department of Labor. Bureau of Labor Statistics. L 2.3/5: (year).

There is no Canadian parallel for this compendium, published approximately every five years. The latest edition has over 500 pages of tables on earnings, unemployment, work stoppages, and so forth. State and industry data are included.

\section{NOTE}

1. U.S., Department of State, Bureau of Public Affairs, U.S.-Canada Free Trade Agreement (Washington: Government Printing Office, 1988), 1 (SuDoc: S 1.2:C 86). 